\title{
Simulation for determining the rod pump system parameter values using finite difference method
}

\author{
Erwani Merry Sartika, Arief Darmawan
}

Department of Electrical Engineering, Universitas Kristen Maranatha, Indonesia

\begin{tabular}{|c|c|}
\hline Article Info & ABSTRACT \\
\hline Article history: & Lifting petroleum to the surface requires a mechanism called an artificial lift. \\
\hline Received Feb 20, 2020 & $\begin{array}{l}\text { This mechanism is useful for increasing the flow of fluids from a well. One that } \\
\text { uses this method is the rod pump. The rod pump system needed the appropriate }\end{array}$ \\
\hline Revised Nov 10, 2020 & design (through the determination of the value of the parameters that affect) so \\
\hline Accepted Dec 5, 2020 & $\begin{array}{l}\text { that the pump runs optimally. But changing the appropriate design in real terms } \\
\text { is not economically and time-efficient. The ideal rod pump system analysis }\end{array}$ \\
\hline Keywords: & $\begin{array}{l}\text { procedure is to take downhole data (in the well) which is commonly called a } \\
\text { pump card. A pump card calculation simulation is needed to efficiently analyze }\end{array}$ \\
\hline Artificial lift & the rod pump system. The wave equation can describe the model of the rod \\
\hline Lifting petroleum & $\begin{array}{l}\text { pump system. A simulation of pump data calculation is performed using the } \\
\text { finite difference method for the wave equation solution. Through the process of }\end{array}$ \\
\hline Pump card & tuning parameter values using trial and error methods, the steps of tuning the \\
\hline Rod pump & parameter value of the rod pump system are proposed in this paper. For further \\
\hline Simulation & $\begin{array}{l}\text { research, a pump card calculation method based on a surface card can be } \\
\text { developed to efficiently analyze the rod pump. }\end{array}$ \\
\hline
\end{tabular}

This is an open access article under the CC BY-SA license.

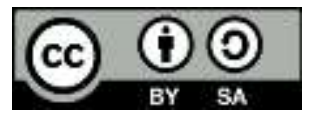

\section{Corresponding Author:}

Erwani Merry Sartika

Department of Electrical Engineering

Universitas Kristen Maranatha

Jln. Suria Sumantri 65 Bandung, Indonesia

Email: erwanimerry@gmail.com

\section{INTRODUCTION}

At present, oil and gas are one of the energies that are still relied on by humans, so the demand for oil and gas is higher. However, to use it a special method is needed to transport this energy source. Therefore, to lift petroleum to the surface a mechanism called an artificial lift is needed. This mechanism is useful for increasing the flow of fluids from a well [1].

The pump is one of the industrial equipment that is widely used today, including in the oil and gas industry. Pump sucker or sucker rod pump is one type of pump in the upstream oil and gas industry that uses the method of artificial lift (power assistance) in the removal of petroleum from the well. This type of pump is usually used in wells that have particles in them and are often also applied to old wells [1]. Surface card data collection methods have been used to analyze the rod pump system. Interpretation of the actual pump conditions of the surface card is very difficult because the data are qualitative and depend on the expertise of the analyzer [2].

Therefore, an analysis procedure is used by taking downhole data (in the well) which is commonly called a pump card. A pump card calculation method based on a surface card is needed to efficiently analyze the actual pump rod system. A pump card calculation method based on a surface card is needed to be able to analyze the actual rod pump system efficiently [3]. Pump card data calculations using the finite difference method have been used to get solutions based on the wave equation [4]. 
Alternative system designs using simulations are carried out to get optimal results [5-8]. Through the pump card data, it is necessary to adjust the parameter values on the rod pump to obtain the ideal pump (optimal) [9]. But changing the parameter values that affect the rod pump in real terms is not economically and time-efficient [10]. Tuning parameter values is mostly done through direct data retrieval by conducting sonological tests to determine the bottom well flow pressure and reservoir pressure. Sonologists work on the principle of waves or sound from the firing or flowing of pressuized gas quickly. Redesign the sucker rod pump without changing the type of pump installed by combining the step length and pump speed, so that volumetric pumping and pump displacement efficiency are obtained based on direct data collection [11].

So, the purpose of this paper is to use simulations to determine the parameter values on the rod pump to get the ideal pump card. Through this simulation, in addition to saving costs and time, it can also be used to anticipate the rod pump if the pump card is not ideal (because it can damage the rod pump). Parameters that can be adjusted and affect the output of the rod pump system is the length of the rod string, the diameter of the rod string, and the speed of the pump [11]. Determination of the parameter value on the rod pump in advance using the trial-and-error method. Through the trial and error method, an analysis is performed to obtain the stages of determining the tuning parameters to accelerate the acquisition of parameter values (through a simulation process).

\section{WORKING PRINCIPLE OF ROD PUMP}

The working mechanism of the rod pump is the working process of all the components contained in the pump shown in Figure 1 [12-14]. The workings of the pump shaft are divided into two, namely on the surface and in the well. The way the rod pump works on the surface is:

a) Prime motion (prime mover) will produce rotational motion, then this motion will be converted into up and down the motion by the pitman crank assembly system. Furthermore, this motion will go through a walking beam and forwarded to the horse head and made straight up and down to move the plunger inside the well.

b) Pumping unit installation above the surface is connected to the pump installation in the well by the sucker rod system, so that the straight up and down motion of the horse head will be moved to the pump plunger, and the plunger will move up and down in the pump barrel.

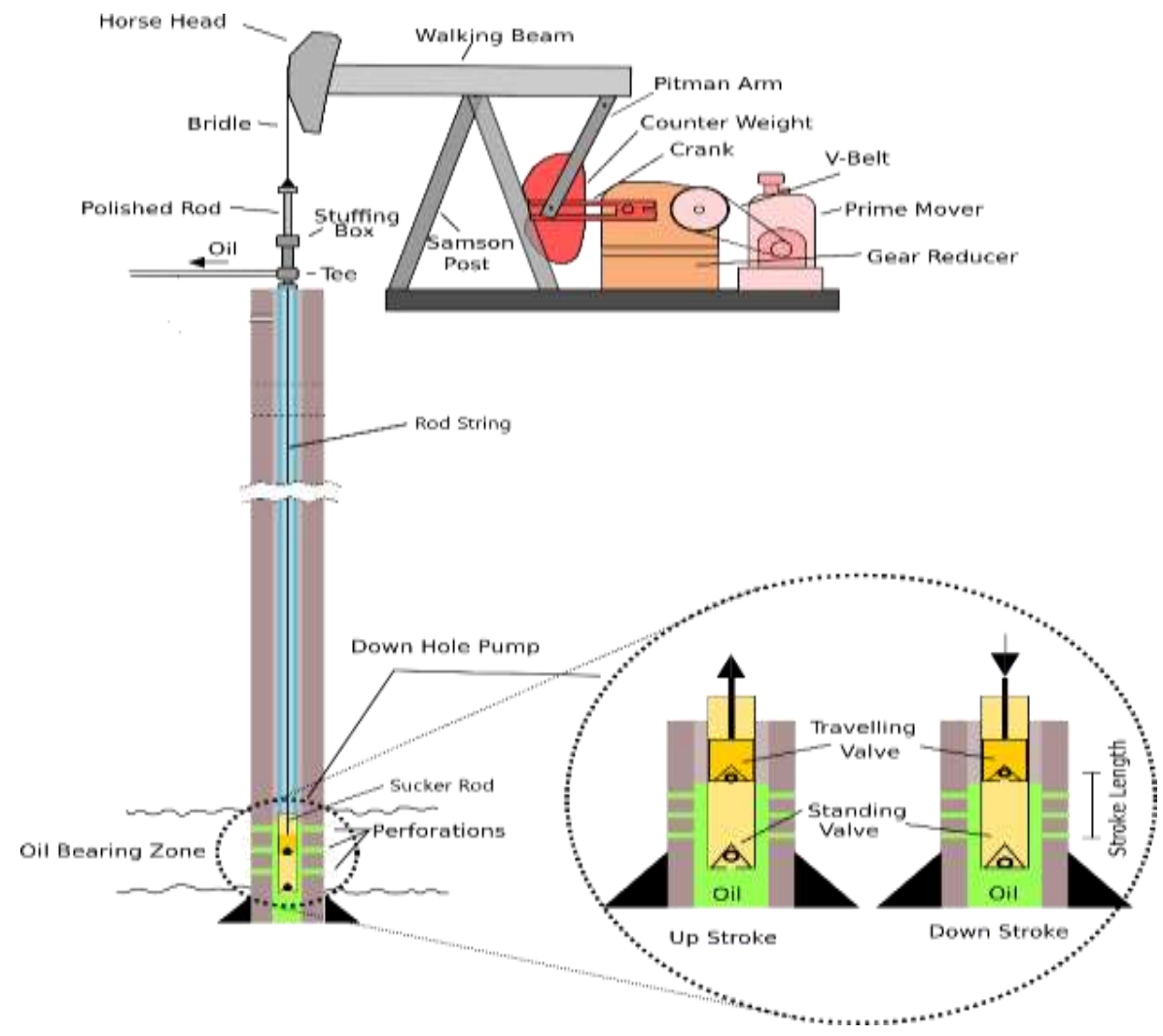

Figure 1. Rod pump components [9] 
The way the rod pump works in the well is:

a) During an upstroke, the plunger will move upwards the traveling valve away from the standing valve, causing the traveling valve to be closed due to pressure from the fluid above it. The fluid can be lifted and out through the pipe. When the plunger moves upward, the pressure in the barrel will decrease to the vacuum pressure, so that the formation pressure will open the standing valve and the fluid will enter the barrel.

b) During the downstroke process, the standing valve will be closed due to the pressure of the liquid above it and the influence of the weight of the balls themselves, while the traveling valve will open and be pushed by the liquid inside the barrel, then the liquid will enter the tubing and lifted due to the pump surface movement. This process will continue until the pipe is filled with fluid and moves to the surface.

\section{DYNAMOMETER CARD}

Dynamometer card is divided into 2 namely surface card and pump card. The surface card displays the load on the rod during the pump cycle and is converted to a pump card that displays the fluid load on the pump during the pump cycle [15-16]. The size and shape of the card show the operating conditions and pump performance as shown in Figure 2. There are 4 points, or 4 sequences that occur when lifting oil. Point 1 to 3 is during the upstroke movement and point 3 to point 1 is during the downstroke movement. Fo (fluid load on the pump) is the process of transferring the valve to fill fluid into the working barrel. Stroke length effective plunger travel (SLEPT), which is the effective stroke length to form the ideal pump card, only occurs when one valve is open and the other closed. Stroke length downhole (SLDH), which is the total stroke length of the downhole plunger [17].

The surface card is the recording of the load on the polished rod against the displacement of the position of the sucker rod which is commonly called the rod through physical sensors mounted on the polished rod. The wave equation is a mathematical model that can estimate the motion of the rod against conditions in the well [18]. A pump card is the recording of the load at the downhole against the displacement of the rod [19].

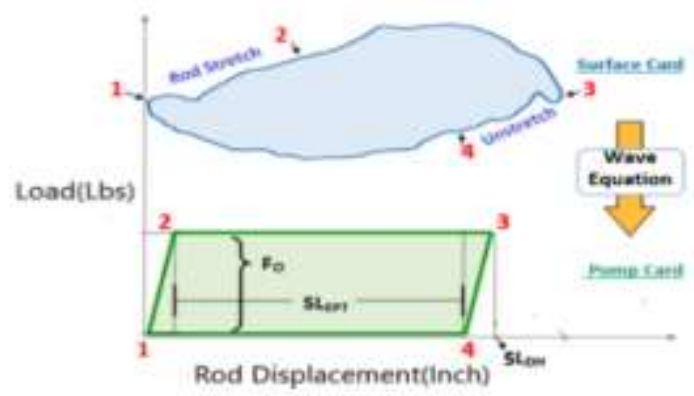

Figure 2. Surface card and pump card [17]

\section{PUMP CARD}

Interpretation of the actual pump conditions of surface cards is very difficult because the data are qualitative and depend on the expertise of the analyzer. The ideal analysis procedure is to take downhole data (under the well) which is commonly called a pump card. There are types of pump cards according to rod pump work and well conditions [17]:
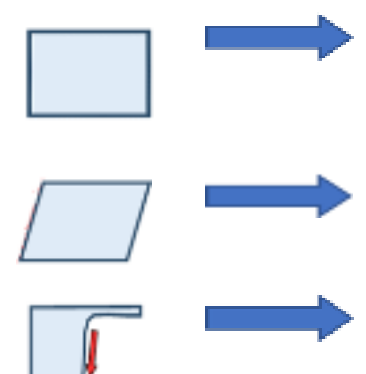

Ideal card: normal pump, full liquid \& no gas interference. The pump is functioning properly

Slanted: there is gas interference which causes a shift in the tubing when lifting

Fluid pound: during downsroke there is an empty space so that it can cause the rod to break when it collides with fluid 


\section{THE WAVE EQUATIONS}

The wave equation is ideal for representing rod movement because it involves wave propagation in continuous media. The wave equation for the rod pump is expressed by (1) [20].

$$
v^{2} \frac{\partial u(x, t)}{\partial x^{2}}=\frac{\partial^{2} u(x, t)}{\partial t^{2}}+c \frac{\partial(x, t)}{\partial t}
$$

In (1) is the wave equation which states that the motion of the rod is not affected by the diameter of the rod string. The wave equation that states the motion of the rod can be affected by the diameter of the rod string can be expressed in (2) [20].

$$
E A \frac{\partial^{2} u(x, t)}{\partial x^{2}}=\frac{\rho A}{144 g_{c}} \frac{\partial^{2} u(x, t)}{\partial t^{2}}+c \frac{\rho A}{144 g_{c}} \frac{\partial u(x, t)}{\partial t}
$$

$\mathrm{E}=$ Modulus Young (Psi)

$\mathrm{A}=$ Transversal Area (inch2)

$\rho=$ Thickness $(\mathrm{lb} / \mathrm{ft} 3)$

$g_{c}=$ Conversion Factor $(\mathrm{lbm} * \mathrm{ft} / \mathrm{lbf} / \mathrm{s} 2)=32.2$

$\mathrm{c}=$ damping coefficient $(\mathrm{s}-1)$

$\mathrm{v}=$ Velocity $(\mathrm{ft} / \mathrm{sec})$

$\mathrm{u}=$ Rod Displacement

The finite difference method is a method for obtaining numerical solutions of partial differential equations [21]. Estimated results of wave equations are discretized using finite difference as shown in (3) [20].

$$
u_{i+1, j}=\left[\frac{\alpha(1+c \Delta t)}{\beta}\right] u_{i, j+1}-\left[\frac{\alpha(2+c \Delta t)-2 \beta}{\beta}\right] u_{i, j}+\frac{\alpha}{\beta} u_{i, j-1}-u_{i-1, j}
$$

$\alpha=\frac{\left(\frac{\Delta x}{\Delta t}\right) \rho A}{144 g c}$

$u_{0 j}=g_{P R_{j}}$

$\beta=\frac{E A}{\Delta x}$

$U_{I j}=\frac{f_{P R_{j} \cdot \Delta_{x}}}{E A}+U_{O, J}$

$\mathrm{g}_{\mathrm{PR}}=$ rod displacement in surface card

$\mathrm{f}_{\mathrm{PR}}=$ fluid load in surface card

The final calculation for rod displacement and fluid load uses (4) and (5) [20] :

$$
\begin{aligned}
& u_{\text {pump,j }}=(1+c \Delta t) u_{m-1, j+1}-c \Delta t u_{m-1, j}+u_{m-1, j-1}-u_{m-2, j} \\
& F_{p u m p, j}=\left(\frac{E A}{2 \Delta x}\right)\left(3 u_{m, j}-4 u_{m-1, j}+u_{m-2, j}\right)
\end{aligned}
$$

$\mathrm{U}=$ rod displacement on pump card

$\mathrm{F}=$ fluid load on pump card

\section{RESEARCH METHOD}

In designing the pump card calculation simulation is divided into three main stages. The first step is to convert the surface card data into pump card data using the wave equation. After getting the pump card data, the parameter data that affects the rod pump system is adjusted. The last step is to analyze the results of the simulation of the rod pump system based on the pump card data.

The surface card image is taken from the database based on references as shown in Figure 3 [22]. Surface card data is in the form of data pairs $\mathrm{X}$ and $\mathrm{Y}$, each of which has 500 points. $\mathrm{X}$ is the displacement data rod and $\mathrm{Y}$ is the data load. It is assumed that the simulation of one cycle of the rod pump system is 360 points (one full rotation of the $360^{\circ}$ motor). Followed by making a matrix of $\mathrm{M}$ rows of 100 , and $\mathrm{N}$ columns of 360 and input $\mathrm{NaN}$ (not a number) data to allocate initial condition data from the matrix. Initialization of 
the first row and the second row of the matrix. The wave equation is used to get the next row (third row to the last row) as shown in the flow diagram of rod pump system simulation in Figure 4.

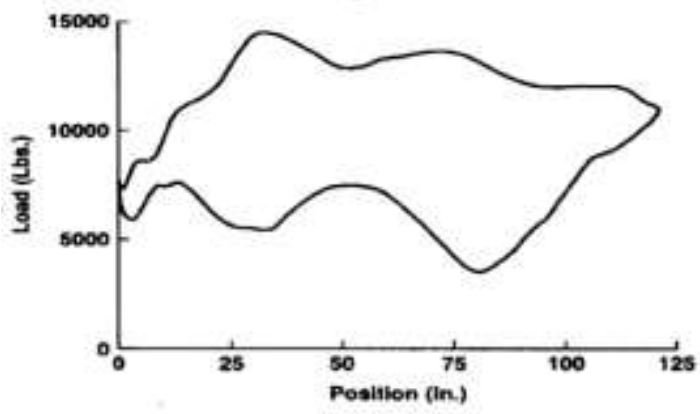

Figure 3. Surface card image[22]

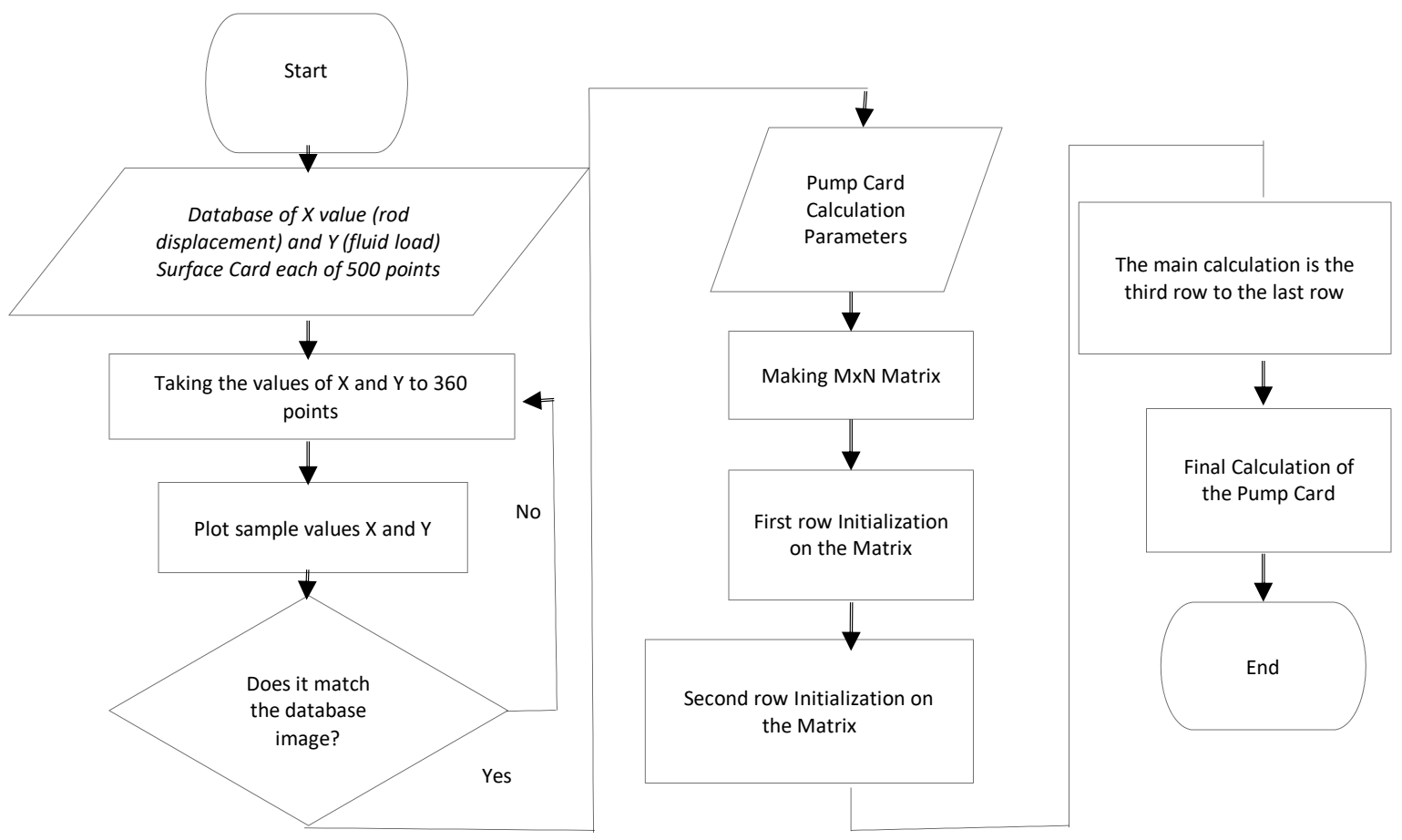

Figure 4. Flow diagram of rod pump system simulation

The parameters used for pump card data calculations can be seen in Table 1. The parameters that will be used as reference parameters for the rod pump system are the parameters of rod string length, rod string diameter, and pump speed because these parameters are parameters that can be changed for the system design rod pump. The other parameters are fixed parameters that cannot be changed [23].

Figure 5 is the final result of the pump card calculation process using a wave equation that has been discretized. The column in the matrix is increased to 720 because if the calculation starts from the surface node $(i=0)$ with only one cycle until the pump solution $(i=m)$ will not represent a complete cycle because to get the main calculation current data and previous data are needed. 360 data columns of the first cycle will be used as current data and previous data to be able to calculate the data that will come incomplete so that no data is lost.

The first row in the matrix is the initialization of the data displacement rod on the surface card. The second row is initializing fluid load data plus data rod displacement on the surface card. The third row to the $\mathrm{m}$-row is the main calculation using the wave equation that has been discretized using finite-difference. NaN is the IEEE arithmetic representation for Not-a-Number [24]. $\mathrm{NaN}$ is used to allocating initial condition data from the matrix (because it cannot be a number including zero) [25]. 
Table 1. The parameters used for pump card calculation simulation [23]

\begin{tabular}{cl}
\hline Parameter & \multicolumn{1}{c}{ Description } \\
\hline E & Modulus Young $($ Psi $)=30,5.10^{6}$ \\
A & Transversal Area $\left.\left(\mathrm{inch}^{2}\right)=\pi /(4 \text {. (diameter })^{2}\right)$ \\
L & Rod String Length $(\mathrm{ft})=$ Parameters to be set \\
v & Speed in one cycle $(\mathrm{SPM})=$ Parameters to be set \\
$\mathrm{D}$ & Diameter of rod string $(\mathrm{inch})=$ Parameters to be set \\
$\mathrm{m}$ & Number of matrix rows for pump card data calculation $=100$ \\
$\mathrm{n}$ & Number of matrix columns for calculation of pump card data $=360$ \\
$\mathrm{c}$ & The damping coefficient $\left(\mathrm{s}^{-1}\right)=0,8$ \\
$\rho$ & Viscosity $(\mathrm{lb} / \mathrm{ft} 3)=490$ \\
$g_{c}$ & Conversion Factor $\left(\mathrm{lbm} . \mathrm{ft} / \mathrm{lbf} / \mathrm{s}^{2}\right)=32.2$ \\
\hline
\end{tabular}

\begin{tabular}{|c|c|c|c|c|c|c|c|c|c|c|c|c|c|c|c|c|c|}
\hline \multicolumn{3}{|c|}{$180 \times 720$} & \multirow[b]{2}{*}{3} & \multirow[b]{2}{*}{$\ldots$} & \multirow[b]{2}{*}{177} & \multirow[b]{2}{*}{178} & \multirow[b]{2}{*}{179} & \multirow[b]{2}{*}{180} & \multirow[b]{2}{*}{$\cdots$} & \multirow[b]{2}{*}{541} & \multirow[b]{2}{*}{542} & \multirow[b]{2}{*}{543} & \multirow[b]{2}{*}{544} & \multirow[b]{2}{*}{$\ldots$} & \multirow[b]{2}{*}{718} & \multirow[b]{2}{*}{719} & \multirow[b]{2}{*}{720} \\
\hline & 1 & 2 & & & & & & & & & & & & & & & \\
\hline 1 & 0.0456 & 0.0465 & 0.0491 & $\ldots$ & 0.1156 & 0.1320 & 0.1501 & 0.1699 & $\ldots$ & 0.1914 & 0.1699 & 0.1501 & 0.1320 & $\ldots$ & 0.0534 & 0.0491 & 0.0465 \\
\hline 2 & 0.0583 & 0.0592 & 0.0618 & $\ldots$ & 0.1284 & 0.1448 & 0.1631 & 0.1831 & $\ldots$ & 0.2007 & 0.1793 & 0.1596 & 0.1416 & $\ldots$ & 0.0652 & 0.0614 & 0.0591 \\
\hline 3 & $\mathrm{NaN}$ & 0.0720 & 0.0745 & $\ldots$ & 0.1411 & 0.1576 & 0.1760 & 0.1963 & $\ldots$ & 0.2100 & 0.1887 & 0.1691 & 0.1513 & $\ldots$ & 0.0771 & 0.0737 & $\mathrm{NaN}$ \\
\hline 4 & $\mathrm{NaN}$ & $\mathrm{NaN}$ & 0.0873 & $\ldots$ & 0.1539 & 0.1704 & 0.1890 & 0.2094 & $\ldots$ & 0.2194 & 0.1981 & 0.1786 & 0.1609 & $\ldots$ & 0.0889 & $\mathrm{NaN}$ & $\mathrm{NaN}$ \\
\hline 5 & $\mathrm{NaN}$ & $\mathrm{NaN}$ & $\mathrm{NaN}$ & $\ldots$ & 0.1666 & 0.1832 & 0.2020 & 0.2226 & $\ldots$ & 0.2287 & 0.2076 & 0.1882 & 0.1705 & $\ldots$ & $\mathrm{NaN}$ & $\mathrm{NaN}$ & $\mathrm{NaN}$ \\
\hline 6 & $\mathrm{NaN}$ & $\mathrm{NaN}$ & $\mathrm{NaN}$ & $\ldots$ & 0.1794 & 0.1961 & 0.2149 & 0.2358 & $\ldots$ & 0.2380 & 0.2170 & 0.1977 & 0.1802 & $\ldots$ & $\mathrm{NaN}$ & $\mathrm{NaN}$ & $\mathrm{NaN}$ \\
\hline 7 & $\mathrm{NaN}$ & $\mathrm{NaN}$ & $\mathrm{NaN}$ & $\ldots$ & 0.1922 & 0.2089 & 0.2279 & 0.2490 & $\ldots$ & 0.2474 & 0.2264 & 0.2072 & 0.1898 & $\ldots$ & $\mathrm{NaN}$ & $\mathrm{NaN}$ & $\mathrm{NaN}$ \\
\hline 8 & $\mathrm{NaN}$ & $\mathrm{NaN}$ & $\mathrm{NaN}$ & $\ldots$ & 0.2050 & 0.2218 & 0.2409 & 0.2622 & $\ldots$ & 0.2567 & 0.2358 & 0.2168 & 0.1994 & $\ldots$ & $\mathrm{NaN}$ & $\mathrm{NaN}$ & $\mathrm{NaN}$ \\
\hline$\vdots$ & $\vdots$ & $\vdots$ & $\vdots$ & & $\vdots$ & $\vdots$ & $\vdots$ & $\vdots$ & & $\vdots$ & $\vdots$ & $\vdots$ & $\bar{\vdots}$ & & & $\vdots$ & \\
\hline 178 & $\mathrm{NaN}$ & $\mathrm{NaN}$ & $\mathrm{NaN}$ & $\ldots$ & 14.9752 & 14.9682 & 14.9594 & 14.9484 & $\ldots$ & 14.9358 & 14.9207 & 14.9033 & 14.8840 & $\ldots$ & $\mathrm{NaN}$ & $\mathrm{NaN}$ & $\mathrm{NaN}$ \\
\hline 179 & $\mathrm{NaN}$ & $\mathrm{NaN}$ & $\mathrm{NaN}$ & $\ldots$ & $\mathrm{NaN}$ & 14.9876 & 14.9787 & 14.9677 & $\ldots$ & 14.9549 & 14.9398 & 14.9223 & $\mathrm{NaN}$ & $\ldots$ & $\mathrm{NaN}$ & $\mathrm{NaN}$ & $\mathrm{NaN}$ \\
\hline 180 & $\mathrm{NaN}$ & $\mathrm{NaN}$ & $\mathrm{NaN}$ & $\ldots$ & $\mathrm{NaN}$ & $\mathrm{NaN}$ & 14.9980 & 14.9870 & $\ldots$ & 14.9741 & 14.9588 & $\mathrm{NaN}$ & $\mathrm{NaN}$ & $\ldots$ & $\mathrm{NaN}$ & $\mathrm{NaN}$ & $\mathrm{NaN}$ \\
\hline
\end{tabular}

Figure 5. Matrix for pump card calculations

\section{RESULTS AND ANALYSIS}

The parameters that influence the formation of the pump card are rod string diameter, rod string length, transverse area, density, damping factor, conversion factor, modulus young, and pump speed. In the simulation that will be tuned are the parameters of the rod string diameter, the length of the rod string, and the speed of the pump as a mechanical design and the process of the rod pump system because the other parameters are fixed coefficients. The pump card data that shows the rod pump system works well is having a large net stroke, a small stroke shift, and a large fluid load with a note that the pump card shape must resemble a rectangle (ideal pump card). Net stroke is an effective stroke to transport the fluid, if the net stroke value increases, the fluid transported will be even greater. Gross stroke is the displacement of a stroke in one pump cycle. The total stroke shift is a gross stroke reduced by a net stroke which represents a stroke that deviates from normal conditions.

In the simulation of the rod pump system, it was conducted preliminary by trial and error method by adjusting the values of the various parameters of the rod pump namely the diameter of the rod string $(0.625$ inches; 0.750 inches; 0.875 inches), the length of the rod string (1000 ft; $2000 \mathrm{ft} ; 3000 \mathrm{ft})$, and the speed of the rod pump in one cycle (8 SPM to 20 SPM). From all trials in Table 2, the results of simulation data are shown which are considered to be representative of all experiments.

From Table 2 the analysis of the tuning process can be concluded. In the initial tuning of the rod string diameter and the length of the rod string, one can be chosen first, because this gives the same results as the effect on the net stroke size, stroke shift, and fluid load. Small diameter rod string and long rod string will produce a large net stroke, small stroke shift, and a large enough fluid load. Meanwhile, to find out the shape of a pump card resembling a rectangle (ideal pump card) is determined by the next step which is the value of the speed of the rod pump in one cycle (SPM). 
Table 2. Simulation results of pump cards with rod string diameter 0.625 inches for various rod string lengths, rod string length 3,000 feet for various rod string diameters, and pump speed 8-20 spm

\begin{tabular}{|c|c|c|c|c|c|c|c|c|c|c|c|c|c|}
\hline $\begin{array}{c}\text { Rod } \\
\text { String } \\
\text { Diameter } \\
\text { (Inch) }\end{array}$ & $\begin{array}{l}\text { Length } \\
\text { of the } \\
\text { rod } \\
\text { string } \\
\text { (ft) }\end{array}$ & $\begin{array}{l}\text { Speed } \\
(\mathrm{SPM})\end{array}$ & $\begin{array}{c}\text { Net } \\
\text { stroke } \\
\text { (inch) }\end{array}$ & $\begin{array}{l}\text { Gross } \\
\text { Stroke } \\
\text { (inch) }\end{array}$ & $\begin{array}{l}\text { Total } \\
\text { Stroke } \\
\text { Shift } \\
\text { (Inch) }\end{array}$ & $\begin{array}{l}\text { Fluid } \\
\text { load } \\
\text { (lbs) }\end{array}$ & $\begin{array}{l}\text { Length } \\
\text { of the } \\
\text { rod } \\
\text { string } \\
\text { (ft) }\end{array}$ & $\begin{array}{c}\text { Rod } \\
\text { String } \\
\text { Diameter } \\
\text { (Inch) }\end{array}$ & $\begin{array}{l}\text { Speed } \\
(\mathrm{SPM})\end{array}$ & $\begin{array}{c}\text { Net } \\
\text { stroke } \\
\text { (inch) }\end{array}$ & $\begin{array}{l}\text { Gross } \\
\text { Stroke } \\
\text { (inch) }\end{array}$ & $\begin{array}{c}\text { Total } \\
\text { Stroke } \\
\text { Shift } \\
\text { (Inch) }\end{array}$ & $\begin{array}{c}\text { Fluid } \\
\text { load } \\
\text { (lbs) }\end{array}$ \\
\hline & & 8 & 71,2 & 133,3 & 62,1 & 11730 & & & 8 & 103,4 & 122,4 & 19 & 11850 \\
\hline & & 9 & 70,8 & 133,1 & 62,3 & 11930 & & & 9 & 104.5 & 120,3 & 15.8 & 12000 \\
\hline & & 10 & 70,5 & 133 & 62,5 & 11970 & & & 10 & 113 & 120,3 & 7.3 & 12200 \\
\hline & & 11 & 70,2 & 132,9 & 62,7 & 11980 & & & 11 & 114.4 & 120,8 & 6.4 & 12250 \\
\hline & & 12 & 69,8 & 132,7 & 62,9 & 12090 & & & 12 & 88,2 & 119,4 & 31,2 & 12400 \\
\hline & & 13 & 69,3 & 132,3 & 63 & 12130 & & & 13 & 87 & 118,8 & 31,8 & 12600 \\
\hline & 1000 & 14 & 69 & 131,9 & 62,9 & 12160 & & 0.625 & 14 & 82,5 & 118,2 & 35,7 & 12700 \\
\hline & & 15 & 68,8 & 131,6 & 62,8 & 12200 & & & 15 & 83,3 & 117,5 & 34,2 & 12700 \\
\hline & & 16 & 68,7 & 131,5 & 62,8 & 13220 & & & 16 & 82,1 & 116,9 & 34,8 & 12800 \\
\hline & & 17 & 68,5 & 131,1 & 62,6 & 13300 & & & 17 & 81,5 & 116 & 34,5 & 13000 \\
\hline & & 18 & 68,3 & 131,2 & 62,9 & 12350 & & & 18 & 80,9 & 116,2 & 35,3 & 13200 \\
\hline & & 19 & 68,2 & 130,9 & 62,7 & 12410 & & & 19 & 80,6 & 115,8 & 35,2 & 13500 \\
\hline & & 20 & 67,5 & 130,6 & 63,1 & 12450 & & & 20 & 80,2 & 115,8 & 35,6 & 13750 \\
\hline & & 8 & 89.8 & 126 & 36.2 & 11800 & & & 8 & 93,8 & 125,8 & 32 & 12200 \\
\hline & & 9 & 92.8 & 126 & 30.2 & 12000 & & & 9 & 94,5 & 125,3 & 30,8 & 12250 \\
\hline & & 10 & 93.3 & 125.5 & 30 & 12100 & & & 10 & 96,2 & 124,6 & 28,4 & 12350 \\
\hline & & 11 & 94.7 & 125.3 & 29.6 & 12500 & & & 11 & 91,9 & 124,1 & 32,2 & 12500 \\
\hline & & 12 & 95 & 125 & 29 & 12630 & & & 12 & 91,5 & 123,5 & 32 & 12750 \\
\hline & & 13 & 96.3 & 124.7 & 28.4 & 12700 & & & 13 & 90,6 & 123 & 32,4 & 12950 \\
\hline \multirow[t]{20}{*}{0.625} & 2000 & 14 & 96.5 & 124.3 & 27.8 & 12890 & 3000 & 0.750 & 14 & 87,7 & 122,3 & 34,6 & 13000 \\
\hline & & 15 & 96.8 & 123.8 & 27 & 13050 & & & 15 & 75,4 & 121,5 & 46,1 & 13200 \\
\hline & & 16 & 83.9 & 123.5 & 39.6 & 13300 & & & 16 & 74,9 & 120,7 & 45,8 & 13450 \\
\hline & & 17 & 82.7 & 123 & 40.3 & 14000 & & & 17 & 73,5 & 120,3 & 46,8 & 13750 \\
\hline & & 18 & 81.8 & 122.4 & 40.6 & 14100 & & & 18 & 72,1 & 120 & 47,9 & 14100 \\
\hline & & 19 & 80.9 & 121.8 & 40.9 & 14350 & & & 19 & 70,3 & 120,1 & 49,8 & 14300 \\
\hline & & 20 & 80.4 & 121.3 & 40.9 & 14600 & & & 20 & 67,3 & 118 & 50,7 & 14850 \\
\hline & & 8 & 103,4 & 122,4 & 19 & 11850 & & & 8 & 79 & 128,8 & 49,8 & 12400 \\
\hline & & 9 & 104.5 & 120,3 & 15.8 & 12000 & & & 9 & 83,6 & 128,2 & 44,6 & 12600 \\
\hline & & 10 & 113 & 120,3 & 7.3 & 12200 & & & 10 & 87,4 & 127,6 & 40,2 & 12750 \\
\hline & & 11 & 114.4 & 120,8 & 6.4 & 12250 & & & 11 & 69,5 & 126,7 & 57,2 & 12900 \\
\hline & & 12 & 88,2 & 119,4 & 31,2 & 12400 & & & 12 & 72 & 126,3 & 54,3 & 13200 \\
\hline & & 13 & 87 & 118,8 & 31,8 & 12600 & & & 13 & 71 & 125,5 & 54,5 & 13400 \\
\hline & 3000 & 14 & 82,5 & 118,2 & 35,7 & 12700 & & 0.875 & 14 & 70,1 & 124,8 & 54,7 & 13700 \\
\hline & & 15 & 83,3 & 117,5 & 34,2 & 12700 & & & 15 & 71 & 124,1 & 53,1 & 14100 \\
\hline & & 16 & 82,1 & 116,9 & 34,8 & 12800 & & & 16 & 71,3 & 123,2 & 51,9 & 14300 \\
\hline & & 17 & 81,5 & 116 & 34,5 & 13000 & & & 17 & 68,3 & 122,3 & 54 & 14800 \\
\hline & & 18 & 80,9 & 116,2 & 35,3 & 13200 & & & 18 & 66,2 & 121,7 & 55,5 & 15100 \\
\hline & & 19 & 80,6 & 115,8 & 35,2 & 13500 & & & 19 & 60 & 120,7 & 60,7 & 15400 \\
\hline & & 20 & 80,2 & 115,8 & 35,6 & 13750 & & & 20 & 58,5 & 119,8 & 61,3 & 15700 \\
\hline
\end{tabular}

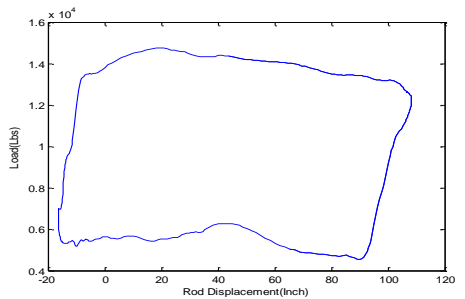

(a)

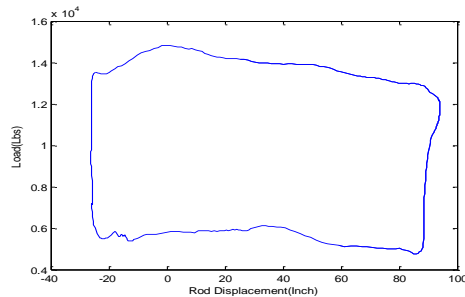

(b)

Figure 6. (a) Pump card with a diameter of 0.625-inch rod string parameter, $2000 \mathrm{ft}$ rod length, and 15 SPM speed. (b) Pump card with 0.625-inch diameter rod string parameters, $3000 \mathrm{ft}$ rod length, and 11 SPM speed 
Some forms of pump cards that are produced from simulations are shown in Figure 6(a) and Figure 6(b). The pump card closest to the ideal shape of the data in Table 3. is at the 15 SPM speed shown in Figure 6(a). At 0.625 -inch rod string diameter, $2000 \mathrm{ft}$ rod length, net stroke value was 96.8 inches, and the total stroke shift was 27 inches. In Figure 6(a) it is shown that the shape of the pump card has formed a rectangle but still needs to look for other values that have a squarer box shape (ideal pump card). The most approaching pump card the ideal shape of the data in Table 2, is at the speed of 11 SPM shown in Figure 6(b). At 0.625 -inch rod string diameter, $3000 \mathrm{ft}$ rod length, net stroke value is 114.4 inches, and the total stroke shift is 6.4 inches.

So the conclusion of the tuning process parameter values on the rod pump is:

1) Can choose the smallest rod string diameter or the longest rod string length for the initial selection of parameter values because both are linear to the net stroke:

a) The smaller the diameter of the rod string, the bigger the net stroke

b) The longer the rod string, the bigger the net stroke

2) If at the beginning choose the smallest rod string diameter, then select the longest rod string or if at the beginning choose the longest rod string, then select the smallest rod string diameter.

3) Then the speed selection (SPM) can then be adjusted from the smallest to the largest, but all conditions must be considered: first, having the largest net stroke, second having the smallest stroke shift, and the third one is having a large enough fluid load and became a square pump card (ideal pump card).

\section{CONCLUSION}

In this paper, a simulation was carried out to obtain the ideal pump card. Through the analysis of simulation results using the trial-and-error method, the tuning process of the parameter values used is to first choose the diameter of the rod string (selected small) and the length of the rod string (selected the longest), followed by the selection of the speed of the rod pump (SPM) which produces a sequence of the largest net stroke, shifting the smallest stroke, and fluid load large enough to approach the ideal shape of the pump card (rectangle). In other paper tuning parameters is done by taking data directly by performing a sonologist test to determine the bottom well flow pressure and reservoir pressure. Based on the simulation the diameter of the rod string is 0.625 inches, the length of the rod string is 3000 feet, and the pump speed of 11 SPM forms the ideal pump card. Based on the tuning process on the proposed rod pump, tuning is done by selecting the smallest rod string diameter and the longest length of the rod string, then continuing to determine the motor speed so that the most ideal pump card is obtained. For further research, a pump card calculation method based on the surface will be developed to analyze the efficiency of the rod pump. Simulation is used to adjust the rod pump parameters directly based on the surface card. In addition, further developments can take advantage of IoT for monitoring real conditions in the field (well conditions) to determine changes in parameter values that affect the performance of the rod pump system.

\section{ACKNOWLEDGEMENTS}

Thank you to PT Danfoss Indonesia for the opportunity given in researching this topic.

\section{REFERENCES}

[1] O. R. ; P. Almeida, "Numerical simulation of the sucker-rod pumping system Simulación numérica de un sistema de bombeo mecánico," Ing. E Investig., vol. 34, pp. 4-11, 2014, doi: 10.15446/ing.investig.v34n3.40835.

[2] X. Xu, R. Gong, Y. Li, J. Li, Q. Li, and Z. Xu, "Binary Histogram of Oriented Gradients Based Dynamometer Card Recognition," in Proceedings - 13th International Conference on Computational Intelligence and Security, CIS 2017, 2018, vol. 2018-Janua, pp. 111-114, doi: 10.1109/CIS.2017.00032.

[3] M. I. Khakimyanov and F. F. Khusainov, "The information processing of dynamometer cards at controllers of automation power drives Sucker Rod Pumps," in 2016 9th International Conference on Power Drives Systems, ICPDS 2016 - Conference Proceedings, 2016, pp. 1-6, doi: 10.1109/ICPDS.2016.7756690.

[4] X. Lv and H. Wang, "A self-evolution fault diagnosis method of sucker rod pump based on simulating dynamometer card," in Proceedings - 2020 12th International Conference on Measuring Technology and Mechatronics Automation, ICMTMA 2020, 2020, pp. 1-6, doi: 10.1109/ICMTMA50254.2020.00009.

[5] J. Liu, J. Feng, and X. Gao, "Fault Diagnosis of Rod Pumping Wells Based on Support Vector Machine Optimized by Improved Chicken Swarm Optimization," in IEEE Access, vol. 7, pp. 171598-171608, 2019, doi: 10.1109/ACCESS.2019.2956221.

[6] B. W. Hansen, "Smart Technologies for Oil Production with Rod Pumping," 2018.

[7] A. Krasovsky, "Simulation and analysis of improved direct torque control of switched reluctance machine," Indones. J. Electr. Eng. Comput. Sci., vol. 18, no. 1, pp. 251-260, 2019, doi: 10.11591/ijeecs.v18.i1.pp251-260.

[8] M. S. K. Bin Jamalus, N. Md. Yusoff, and A. Hadi Sulaiman, "Simulation of dual stage thulium-doped fiber 
amplifier using pump power distribution technique,” Indones. J. Electr. Eng. Comput. Sci., vol. 15, no. 3, p. 1203, 2019, doi: 10.11591/ijeecs.v15.i3.pp1203-1211.

[9] L. W. White, "Predicting Behavior of Sucker-Rod Pumping Systems With Optimal Control," J. Dyn. Syst. Meas. Control, no. October, pp. 1-17, 2017, doi: 10.1115/1.4038112.

[10] A. V. Semenov, S. I. Tecle, and A. Ziuzev, "Modeling Induction Motor Driven Sucker Rod Pump in MATLAB Simscape," in Proceedings - 2020 Russian Workshop on Power Engineering and Automation of Metallurgy Industry: Research and Practice, PEAMI 2020, 2020, pp. 67-71, doi: 10.1109/PEAMI49900.2020.9234336.

[11] S. I. Tecle and A. Ziuzev, "A Review on Sucker Rod Pump Monitoring and Diagnostic System," in Proceedings 2019 IEEE Russian Workshop on Power Engineering and Automation of Metallurgy Industry: Research and Practice, PEAMI 2019, 2019, pp. 85-88, doi: 10.1109/PEAMI.2019.8915296.

[12] A. Wang et al., "Tracking the multi-well surface dynamometer card state for a sucker-rod pump by using a particle filter," in IET Communications, vol. 12, no. 16, pp. 2058-2066, 2018, doi: 10.1049/iet-com.2018.5331.

[13] A. N. Ladygin, D. D. Bogachenko, V. V. Kholin, and N. A. Ladygin, "Method of Efficient Control of the SuckerRod Pump Electric Drive," in 2020 27th International Workshop on Electric Drives: MPEI Department of Electric Drives 90th Anniversary, IWED 2020 - Proceedings, 2020, pp. 4-7, doi: 10.1109/IWED48848.2020.9069584.

[14] B. Zheng, X. Gao, and R. Pan, "Sucker Rod Pump Working State Diagnosis Using Motor Data and Hidden Conditional Random Fields," in IEEE Transactions on Industrial Electronics, vol. 67, no. 9, pp. 7919-7928, 2020, doi: 10.1109/TIE.2019.2944081.

[15] X. Li, X. Gao, C. Yuan, Y. Hou, and X. Chen, "Practical Parameter Estimator for Dynamometer Card of Rod Pumping Systems by Measuring Terminal Data of Drive Motor," in Proceedings of the 31st Chinese Control and Decision Conference, CCDC 2019, 2019, pp. 4074-4077, doi: 10.1109/CCDC.2019.8833370.

[16] H. Hu et al., "The Development and Application of Dynamometer Card Measurement and Analysis System Based on Andriod Platform," in Proceedings - 2016 8th International Conference on Computational Intelligence and Communication Networks, CICN 2016, 2017, pp. 150-154, doi: 10.1109/CICN.2016.35.

[17] D. Diagnostic, "Sucker Rod Pumping Short Course," vol. 2. pp. 1-6, 2014, [Online]. Available: https://0aa73c5e5e00-4b64-90ea-7763a66d9c30.filesusr.com/ugd/f8ee70_d4ba77a8b77e40d898037b28bebad23e.pdf.

[18] T. Sun, J. Shi, M. Dai, L. Xu, Y. Wang, and F. L. Jin, “Application of automatic gauging technology of rod pump dynamometer card in the oilfield," in Proceedings - 2011 IEEE International Conference on Computer Science and Automation Engineering, CSAE 2011, vol. 1, no. 1, 2011, pp. 399-403, doi: 10.1109/CSAE.2011.5953248.

[19] A. M. Zyuzev, M. V. Bubnov, and M. V. Mudrov, "Sucker-rod pump unit electric drive simulator," in 2016 2nd International Conference on Industrial Engineering, Applications and Manufacturing, ICIEAM 2016 Proceedings, 2016, pp. 0-3, doi: 10.1109/ICIEAM.2016.7911522.

[20] M. P. Lamoureux, "The mathematics of PDEs and the wave equation," Seism. Imaging Summer Sch. August 7-11, 2006, Calgary, pp. 1-39, 2006, [Online]. Available: http://www.mathtube.org/sites/default/files/lecturenotes/Lamoureux_Michael.pdf.

[21] S. C. Chapra and R. P. Canale, Numerical Methods for Engineers, Seventh Ed. New York: McGraw-Hill Science/Engineering/Math, 2015.

[22] T. A. Everitt, C. Oil, J. W. Jennings, and A. Texas, "An Improved Finite-Difference Calculation of Downhole Dynamometer Cards for Sucker-Rod Pumps," SPE Prod. Eng., no. February, pp. 121-127, 1992, doi: 10.2118/18189-PA.

[23] E. P. Specification, "European Patent Specification,” 2018.

[24] D. Houcque, Introduction To Matlab for Engineering Students, no. August. 2005.

[25] MatLab, Programming Fundamentals R 2014 b. 2014.

\section{BIOGRAPHIES OF AUTHORS}

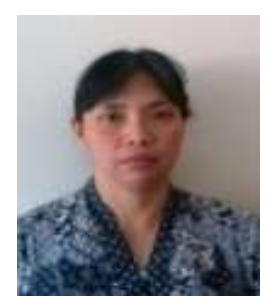

Erwani Merry Sartika, a lecturer in the electrical engineering study program at Universitas Kristen Maranatha. She explored the field of control systems and system identification. Her work focuses on the role of automation, modeling, and simulation.

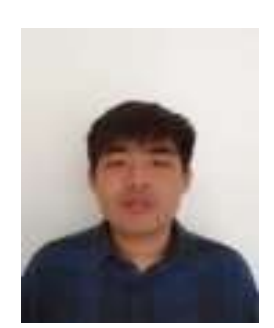

Arief Darmawan, a graduate of the Electrical Engineering Department at Universitas Kristen Maranatha in Bandung, and his area of expertise is computer programming. He was born in 1996 in Bogor and had an internship at PT Danfoss Indonesia. 